\title{
P01.42. Dose-dependent effects of massage-like loading in an animal model following eccentric exercise
}

\author{
T Best ${ }^{*}$, Y Zhao, D Jarjoura, X Zhang, C Haas \\ From International Research Congress on Integrative Medicine and Health 2012 \\ Portland, Oregon, USA. 15-18 May 2012
}

\section{Purpose}

Determine the effects of duration, magnitude, and frequency of massage-like compressive loading on the recovery of active muscle properties (torque - joint angle) following a bout of damaging eccentric exercise.

\section{Methods}

Twenty-four New Zealand white rabbits were surgically instrumented and underwent a bout of damaging eccentric exercise to the tibialis anterior muscle. Rabbits were randomly assigned to a protocol with massage frequency of 0.25 or $0.50 \mathrm{~Hz}$ at a compressive force of 5 or $10 \mathrm{~N}$ for 15 or 30 minutes. The contralateral limb served as the exercised, non-massaged control. A torque-angle relationship was obtained for 21 tibiotarsal joint angles, pre- and post-exercise, and post four consecutive days of massage (applied by customized device). Peak isometric torque was the primary outcome variable. Muscle wet weight and histological analysis were also performed at the end of the protocol.

\section{Results}

Greatest recovery of peak isometric torque occured at the $0.5 \mathrm{~Hz}, 10 \mathrm{~N}, 15 \mathrm{~min}$ condition showing a recovery index of 1.083 [RI]. Analysis showed a significant difference for the RI of the massaged hindlimb between the two magnitudes (5 and $10 \mathrm{~N} ; \mathrm{p}=0.004$ ) and the two frequencies $(0.25$ and $0.5 \mathrm{~Hz} ; \mathrm{p}=0.012)$ but no difference for the two durations $(15 \mathrm{~min}$ and $30 \mathrm{~min})$. Muscle wet weight showed massaged animals tissue weighing $(\mathrm{n}=12)$ $3.22+/-0.61 \mathrm{~g}$, while the control (non-massaged) tissue weighed $(\mathrm{n}=9) 3.74+/-0.65 \mathrm{~g}(\mathrm{p}<0.05)$. Histology verified

\footnotetext{
The Ohio State University, Columbus, USA
}

() 2012 Best et al; licensee BioMed Central Ltd. This is an Open Access article distributed under the terms of the Creative Commons Attribution License (http://creativecommons.org/licenses/by/2.0), which permits unrestricted use, distribution, and reproduction in the beneficial effects of massage through decreased myofiber damage and cellular infiltration.

\section{Conclusion}

There is a dose-response effect with respect to magnitude and frequency of massage-like compressive forces on recovery of active muscle properties following eccentric exercise in an animal model. These results may help to explain the variability in human studies evaluating the efficacy of this therapy for recovery from intense exercise.

Published: 12 June 2012

doi:10.1186/1472-6882-12-S1-P42

Cite this article as: Best et al:: P01.42. Dose-dependent effects of massage-like loading in an animal model following eccentric exercise. BMC Complementary and Alternative Medicine 2012 12(Suppl 1):P42.

Submit your next manuscript to BioMed Central and take full advantage of:

- Convenient online submission

- Thorough peer review

- No space constraints or color figure charges

- Immediate publication on acceptance

- Inclusion in PubMed, CAS, Scopus and Google Scholar

- Research which is freely available for redistribution

Submit your manuscript at www.biomedcentral.com/submit any medium, provided the original work is properly cited. 